\title{
RESEÑA DE TESIS DOCTORAL. LA REALIDAD DIRIGIDA EN LOS PROGRAMAS DE TELERREALIDAD: ANÁLISIS DE CALLEJEROS Y VIDAS ANÓNIMAS
}

Carmen Costa Sánchez ${ }^{1}$

Universidade da Coruña

Material original autorizado para su primera publicación en la revista académica REDMARKA. Revista Digital de Marketing Aplicado.

https://doi.org/10.17979/redma.2011.01.06.4723

Reseña de tesis doctoral:

Brenda Vázquez La Hoz, La realidad dirigida en los programas de telerrealidad: análisis de Callejeros y Vidas Anónimas. Tesis doctoral presentada y defendida el 03 de junio de 2011, en la Facultad de Ciencias Sociales y de la Comunicación de la Universidade de Vigo, calificada de Sobresaliente cum Laudem.

Palabras clave: Telerrealidad, reportaje, documental, docudrama, programación.

\section{$\mathrm{PhD}$ review}

Brenda Vázquez La Hoz, La realidad dirigida en los programas de telerrealidad: análisis de Callejeros y Vidas Anónimas. PhD presented and defended in June 3rd 2011, in the Social Sciences Faculty, Universidade de Vigo, qualified Sobresaliente cum Laudem.

Keywords: TVreality, interview, documentary, docudrama, programming

\footnotetext{
${ }^{1}$ Carmen Costa Sánchez es Doctora en Comunicación por la Universidad de Santiago de Compostela y profesora de Narrativa Audiovisual y de Guion de la Universidade da Coruña.
} 
La tesis "La realidad dirigida en los programas de telerrealidad: análisis de Callejeros y Vidas Anónimas" de la doctora Brenda Vázquez La Hoz se adentra en la investigación sobre uno de los nuevos formatos de televisión que están transformando los contenidos audiovisuales y las parrillas de las televisiones en abierto. Desde el punto de vista de la construcción y presentación del relato informativo introducen novedades que enriquecen las tradicionales formas de elaboración, modificando el papel del periodista y de la cámara en el proceso de captación y transmisión del hecho informativo. Por lo que respecta a la conformación de la oferta, los programas de reportajes de telerrealidad o docurrealidad son un producto integrado en la amplia oferta de formatos que pretenden convertir al individuo anónimo y su peripecia personal en protagonista de los programas. Como apunta la doctora La Hoz en su tesis, la realidad dirigida o telerrealidad ha conseguido, en términos generales, alejarse del tratamiento propio de los productos encuadrados en lo que se conoce como telebasura.

La tesis se estructura sobre cuatro grandes bloques. El primero fundamenta el objeto de estudio y la relevancia del trabajo de investigación; agrupa los capítulos que se ocupan de la información audiovisual, el reportaje como género de la información audiovisual y los orígenes de la telerrealidad. En ellos se presenta una evolución del reportaje y su interrelación con el documental informativo, a los que se caracteriza como antecedentes del producto del que se ocupa la tesis doctoral.

El segundo bloque aborda el análisis de la producción de este tipo de programas a partir de las rutinas de trabajo de los dos sobre los que se realiza la investigación. Es en este apartado donde se refleja la evolución de la audiencia de los programas a lo largo de tres temporadas, estableciendo el peso de los mismos en las audiencias totales de las emisoras que los programan. Las cifras que se ofrecen revelan la importancia relativa de ambos productos, emitidos por cadenas que no superan el ocho por ciento de cuota de pantalla. 
El tercer bloque que estructura la tesis amalgama el análisis de la situación a la fecha de la elaboración del trabajo, las perspectivas de futuro de la telerrealidad y, lo que constituye un hecho significativo para la doctora La Hoz, las diferencias entre la telerrealidad y la telebasura, que si los profesionales y los estudiosos de la comunicación audiovisual perciben nítidamente, la audiencia puede confundir influida por determinados contenidos que se sirven de las vidas de personajes famosos o anónimos para elaborar productos de escasa calidad y nulo valor informativo.

El cuarto bloque detalla la conclusiones de la investigación, que fijan el resultado del análisis realizado por la doctora La Hoz en su tesis. Cabe destacar que se concluye que la telerrealidad sigue la teoría de la construcción social de la realidad, que es el resultado de la tendencia a la espectacularización de la información y que, cada vez más, en este tipo de programas se apela a las emociones y no se profundiza en los verdaderos conflictos de los ciudadanos.

El trabajo de investigación parte de la hipotésis de que este tipo de programas dirigen a personas corrientes para que formen parte del espectáculo audiovisual. Siendo un punto de partida válido, la evolución de la oferta nos revela que el protagonista puede ser un sujeto anónimo, pero también un sujeto conocido por la comunidad o una persona con una posición especial debido a circunstancias económicas o de otro tipo. El objetivo informativo queda mediatizado por el hecho de que el protagonista de la información es el actor, ante el que el periodista adopta una posición secundaria, pero al mismo tiempo, directiva: dirige al "actor" informativo tratando de que fluya de la forma más verosímil posible lo que éste tiene que mostrar.

La peculiaridad de la telerrelidad informativa o docurrealidad queda patente en la utilización de la cámara y el tipo de montaje que se realiza con el material grabado, tal como explica la tesis de la doctora La Hoz. El objetivo capta unas imágenes que posteriormente se ensamblan buscando la mayor fidelidad 
posible con el hecho real que han captado. El montaje limitado, el plano secuencia como recurso de grabación y el sonido directo pretenden un ritmo narrativo que aparezca a los ojos del espectador como el más puro posible, sin mediación que altere la realidad ni siquiera de forma involuntaria.

La metodología de la tesis se ha basado en el análisis de los datos de audiencia de los dos programas y su evolución a lo largo de las temporadas que abarcan desde 2007 hasta 2010 y su comparación con los de otros formatos; la autora también se ha entrevistado con los miembros de los equipos que los elaboran y ha visionado una muestra significativa de Vidas Anónimas y Callejeros con el fin de desentrañar su proceso de elaboración y establecer una comparación con otros programas de telerrelidad.

La tesis de la doctora $\mathrm{La} \mathrm{Hoz} \mathrm{constituye} \mathrm{una} \mathrm{interesante} \mathrm{y} \mathrm{rigurosa}$ aproximación científica a un tipo de programa que ha proliferado en las parrillas de la programación de las televisiones en España en las franjas de más audiencia. Con los problemas que genera la falta de una perspectiva histórica más amplia y los beneficios derivados de la observación participante de la autora (que durante varios años ha trabajado como periodista en uno de los dos programas objeto de estudio, que por tanto conoce muy de cerca), esta investigación aporta una visión sistemática de gran valía acerca de la morfología, objetivos, valor económico y repercusión social de los programas de reportajes de telerrealidad. 